\title{
Spread of Aedes japonicus japonicus (Theobald, 1901) in Austria, 2011-2015, and first records of the subspecies for Hungary, 2012, and the principality of Liechtenstein, 2015
}

Bernhard Seidel ${ }^{1,2^{*}}$, Norbert Nowotny ${ }^{3,4^{*}}$, Tamás Bakonyi ${ }^{3,5}$, Franz Allerberger ${ }^{6}$ and Francis Schaffner ${ }^{7,8}$

\begin{abstract}
Background: The Asian bush mosquito, Aedes (Hulecoeteomyia) japonicus japonicus (Theobald, 1901) (Diptera: Culicidae), was first identified in Austria in August 2011 in the federal state of Styria at the border to Slovenia.

Methods: Between 2011 and 2015 the spread of Ae. j. japonicus was monitored in southern, eastern and western Austrian provinces as well as in neighbouring countries by checking natural and man-made container habitats for the aquatic stages. The search concentrated around the most recent occurrence of Ae. j. japonicus and extended up to several kilometres until the subspecies could not be found anymore.

Results: Between May and July 2012 the distribution area of Ae. j. japonicus was found to be extended westwards into Carinthia, and eastwards towards the federal state of Burgenland. In August 2012, the subspecies was found in Hungary, representing the first record of an invasive mosquito species in this country. In 2013 its expansion was confirmed at several sites in Austria. Additionally, between April and July 2015, the subspecies was detected in all districts of the westernmost Austrian state Vorarlberg reaching the alpine Montafon valley at the end of October 2015, at all three examined sites in southern Bavaria bordering Vorarlberg, and in the adjacent Principality of Liechtenstein, for which it also represents the first record of an invasive mosquito species. One remarkable finding of the subspecies was located close to the city of Kufstein in the lower Inn valley of the Tyrol in September 2015, which is an isolated occurrence without spatial connection to any known established population.

(Continued on next page)
\end{abstract}

\footnotetext{
*Correspondence: bernhard.seidel@univie.ac.at; norbert.nowotny@

vetmeduni.ac.at; norbert.nowotny@mbru.ac.ae

${ }^{1}$ Technical Office of Ecology and Landscape Assessment, Nibelungenstrasse 51, A-3680 Persenbeug, Austria

${ }^{4}$ Department of Basic Medical Sciences, College of Medicine, Mohammed Bin

Rashid University of Medicine and Health Sciences, Dubai Healthcare City,

P.O. Box 505055, Dubai, United Arab Emirates

Full list of author information is available at the end of the article
} 
(Continued from previous page)

Conclusions: Our findings demonstrate the ongoing spread of Ae. j. japonicus towards all directions within Austria and beyond. Together with the absence of supposed natural barriers, e.g. high mountain chains, at the borders of the current subspecies' distribution area in south-eastern Austria, these findings suggest a further spread to the Austrian capital Vienna and the Hungarian tourist region of Lake Balaton within the upcoming few years. The observed intrusions in western Austria represent most probably extensions of the population established and spreading in eastern Switzerland and southern Germany. The putative role of the subspecies in pathogen transmission together with its rapid spread observed argues for the implementation of comprehensive nation-wide surveillance and response preparedness.

Keywords: Aedes japonicus, Asian bush mosquito, Invasive mosquito species, Active spread, First record, Austria, Hungary, Bavaria, Liechtenstein

\section{Background}

Evidence of invasive mosquito populations in zones of temperate climate has extensively been reported for Europe [1]. Since the Asian bush mosquito Aedes (Hulecoeteomyia) japonicus japonicus (Theobald, 1901) (taxonomic nomenclature according to [2]) was found established in Belgium in 2002 [3] and later in Switzerland and southern Germany in 2008 [4], several further colonised areas have been reported from other parts of Europe to date (summarised in [5]).

Aedes japonicus japonicus was incidentally discovered in a remote mountainous region in the south of the Austrian province of Styria bordering to Slovenia in August 2011 [6]. Follow-up studies found the subspecies widespread around the city of Maribor in neighbouring Slovenia in September 2011 [6]; however only limited further investigations were carried out there to determine more extensively its distribution [7]. The introduction of Ae. j. japonicus into that area could not be backtracked. In October 2011, its distribution in Austria covered an area extending to the Slovenian border southwards and to the Styrian capital Graz northwards. In the neighbouring province of Carinthia, only one specimen of Ae.j. japonicus was found near the city of Lavamünd (46.634562N, 14.954196E; $360 \mathrm{~m}$ above sea level, m.a.s.l.), located at the border to Slovenia. Despite intensive mosquito sampling around Lavamünd, no further Ae. j. japonicus individuals were detected there, and thus this location can be considered the westernmost distribution of the subspecies in Austria in 2011. A similar belt of Ae. j. japonicus-negative sites was also observed towards the north and northeast around the 2011 Styrian distribution area (Fig. 1).

Although the subspecies was already reported from several European countries (summarised in $[1,5]$ ), a rapid colonisation of these areas was not generally observed [3, 8]. Thus, in 2011 it was not clear if and how fast further active expansion of the distribution area of Ae. j. japonicus would happen and whether new introductions (e.g. through passive transportation) will be necessary to maintain this invasive subspecies in the region [9]. Therefore, we decided to further investigate the area to determine whether Ae. j. japonicus is further spreading in south-eastern Austria and could reach the bordering Hungarian and Italian regions. Because of the existence of several separated Ae. j. japonicus populations in Switzerland and Germany, we extended our mosquito surveillance activities since autumn 2011 also to the most western Austrian province of Vorarlberg with particular attention to the boundaries of Germany and Switzerland.

\section{Methods}

In August 2011, the Ae. j. japonicus surveillance activities were started around the few known breeding sites in southeastern Austria (Styria, Carinthia). In western Austria (Vorarlberg), the surveillance started in 2011 and was intensified in 2015. Inspections were performed at sites that looked suitable for the subspecies, mostly at human settlements and more rarely in forests, by search of immature life stages in container habitats, both manmade (tyres, barrels, vases, etc.) and natural (rock pools, tree holes). Despite artificial water-filled vessels acting as oviposition traps proved to be efficient to survey Ae. $j$. japonicus [10], we choose to use available breeding sites to survey the spread of the species. This allows to observe the ecological behaviour of the species in the local context and avoids repetitive visits (deposit of ovitraps and successive checking) that would have increased the cost of the surveillance. When the survey demonstrated the presence of the subspecies in a given area, we investigated the surroundings up to distant spots where we did not find the subspecies anymore.

Based on the hypothesis of dispersal by traffic transportation, three survey sites were selected in different directions and at distances of approximately $60 \mathrm{~km}$ from the sites of first detection in Styria and in Carinthia, respectively. These "control point" sites served as "sentinel" sites in order to detect at an early stage a nonpredictable spread by e.g. passive transportation. These 


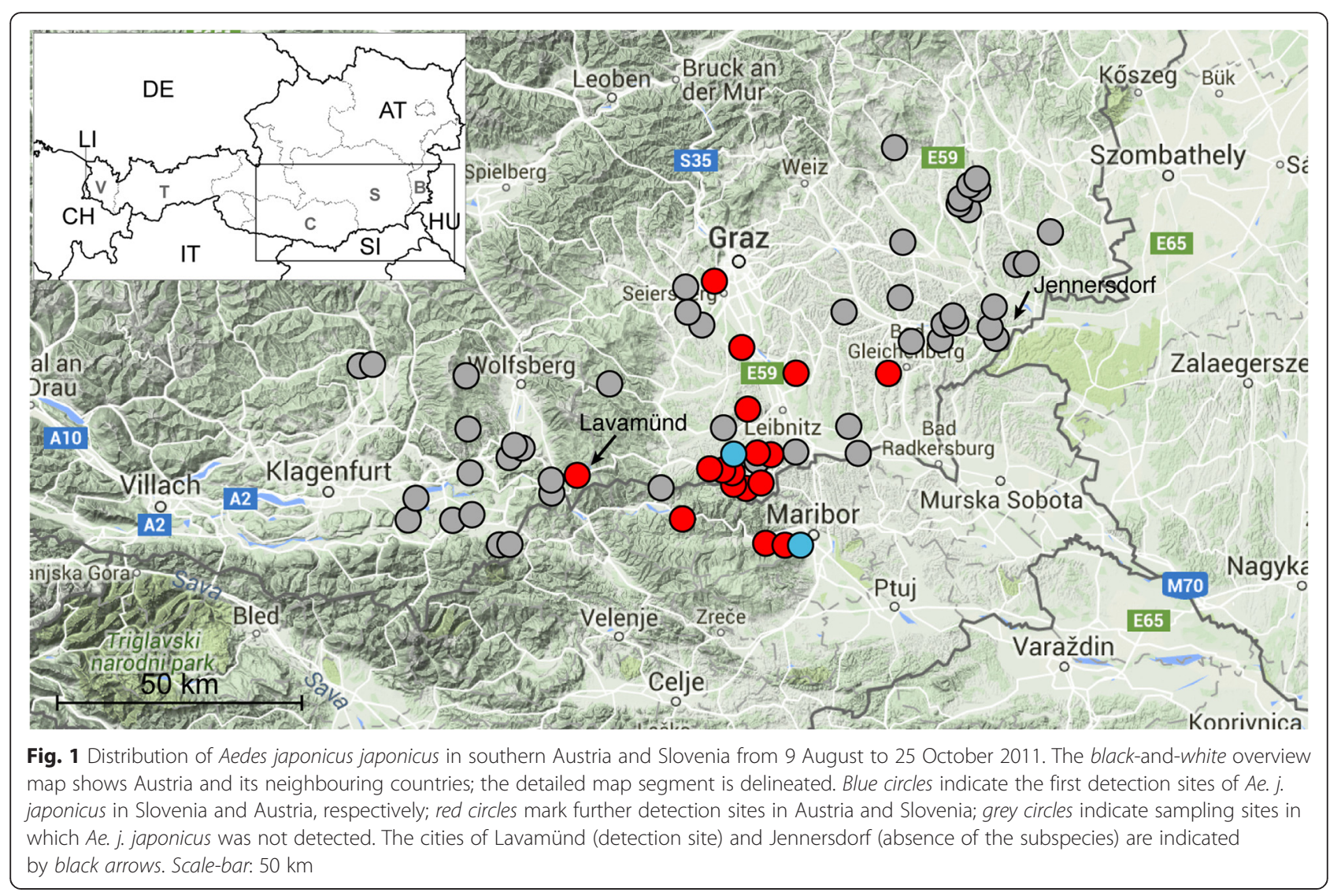

three "control points" were located along possible spreading routes like ecological corridors (e.g. valleys of rivers Drau, Glan, and Raab) and major traffic routes, and were examined for immature stages at least three times per season since 2012: (i) Hackerberg/Burgenland as a "control point" towards Vienna (47.195047N, 16.105060E; 299 m.a.s.l.); (ii) Unterloibl in southern Carinthia, as a "control point" towards Italy $(46.508390 \mathrm{~N}, 14.290065 \mathrm{E}$; 501 m.a.s.l.); and (iii) Unterbergen-Althofen in northern Carinthia as a "control point" towards western Styria and the River Mur valley (46.876278N, 14.449979E; 606 m.a.s.l.). The bordering Hungarian region was investigated once in 2012.

In western Austria, the surveillance was first focusing on a few places in the federal state Vorarlberg, because of the known presence of a population in neighbouring Switzerland, and its probable spread. Later, following the finding of the subspecies in Vorarlberg's Hohenweiler, the surveillance was extended into a systematic investigation including the whole of Vorarlberg and also areas in all three neighbouring countries (Bavaria/Germany, Liechtenstein and Switzerland). Besides the designed study, a specific short mission was performed in Liechtenstein by checking putative container habitats in cemeteries; this was planned within the VectorNet project, in order to confirm the presence or absence of
Ae. j. japonicus in the Principality and thus fill a gap in the VectorNet database and the related species' distribution map (http://ecdc.europa.eu/en/healthtopics/vectors/ vector-maps/Pages/VBORNET_maps.aspx).

Collected immature specimen samples were brought to the laboratory for morphological identification of larvae and emerged adults according to the key by Schaffner et al. [11].

\section{Results and discussion}

South-eastern Austria and neighbouring regions of Slovenia and Hungary

In 2012 the expansion of the subspecies' distribution range was investigated in Carinthia westwards. Referring to the previous single Ae. j. japonicus occurrence detected in Carinthia on 24 September 2011 at the border to Slovenia (Fig. 1), the subspecies' distribution range was found expanded up to $10 \mathrm{~km}$ to the west and northwest by April 2012 (29 April 2012: St. Georgen, $46.714629 \mathrm{~N}, 14.900279 \mathrm{E}, 499$ m.a.s.l.), and up to $27 \mathrm{~km}$ by September 2012 (18 September 2012, Stift Griffen, 46.703951N, 14.702619E, 526 m.a.s.l.; 19 September 2012, Eitweg, 46.780202N, 14.893086E, 624 m.a.s.l.).

Towards the north, four Ae. j. japonicus females were attracted by a human bait created by one of the authors (BS) on 11 July 2012 in the city centre of Graz, the 
capital of Styria, alongside the main railroad station (Europaplatz, 47.072134N, 15.419154E; 371 m.a.s.l.).

Eastwards, several places in the direction towards Hungary were inspected, e.g. around the city of Jennersdorf (46.938036N, 16.1078740E; 245 m.a.s.l.) on 31 August 2011 and again on 29 May 2012, without finding any evidence for the presence of the subspecies. Since 17 July 2012, however, the subspecies was found at several locations around Jennersdorf (Fig. 2). The distance to the Hungarian border from these places is less than $10 \mathrm{~km}$. On $9 \mathrm{Au}$ gust 2012, numerous Ae. j. japonicus larvae were found associated with Culex pipiens and $C x$. hortensis in rainwater barrels of two separated sites in Felsöszölnök, Hungary (46.885302N, 16.182786E; 267 m.a.s.l. and $46.874208 \mathrm{~N}, 16.182733 \mathrm{E} ; 314$ m.a.s.l.). These represent the first records of an invasive mosquito species and in particular of Ae. j. japonicus in Hungary. The occurrence of 50 autochthonous culicid species was recently reported for Hungary [12]. The invasive mosquito subspecies Ae. j. japonicus and the Asian tiger mosquito Aedes (Stegomyia) albopictus (Skuse, 1894) were not listed among the Hungarian mosquito fauna, but it was postulated that the latter may appear in Hungary in the future [12]. Interestingly, the species' border crossing did not occur along a lowland river region that was surveyed, but more southern in a hilly and woody area, which underlines the species' preferences for bush and woodland landscape.

Surveillance 2013-2015: While the "thermal spa tourist" region of eastern Styria and southern Burgenland was already widely colonised by Ae. j. japonicus in July 2012, the subspecies was found in the northern parts of this tourist region in early October 2013 (first at our "control point" Hackerberg/Burgenland), midway between its first record in southern Styria and the Austrian capital Vienna. We also confirmed the occurrence of Ae. $j$. japonicus in central Styria around the city of Leoben on 2 November 2013. The western part of Styria might be colonised by the subspecies spreading northward from Carinthia via a pass connection to the city of Neumarkt in Styria (our nearby second "control point" UnterbergenAlthofen in Carinthia proved positive since 28 July 2015). In October 2014 the subspecies was caught for the first time at our third "control point" Unterloibl in southern Carinthia. From there, the subspecies has spread further to Italy, as confirmed by its detection there in 2015 [13].

\section{Western Austria and neighbouring regions of Germany, Switzerland and Liechtenstein}

Since September 2011 mosquito surveillance was also carried out in the westernmost Austrian province Vorarlberg,

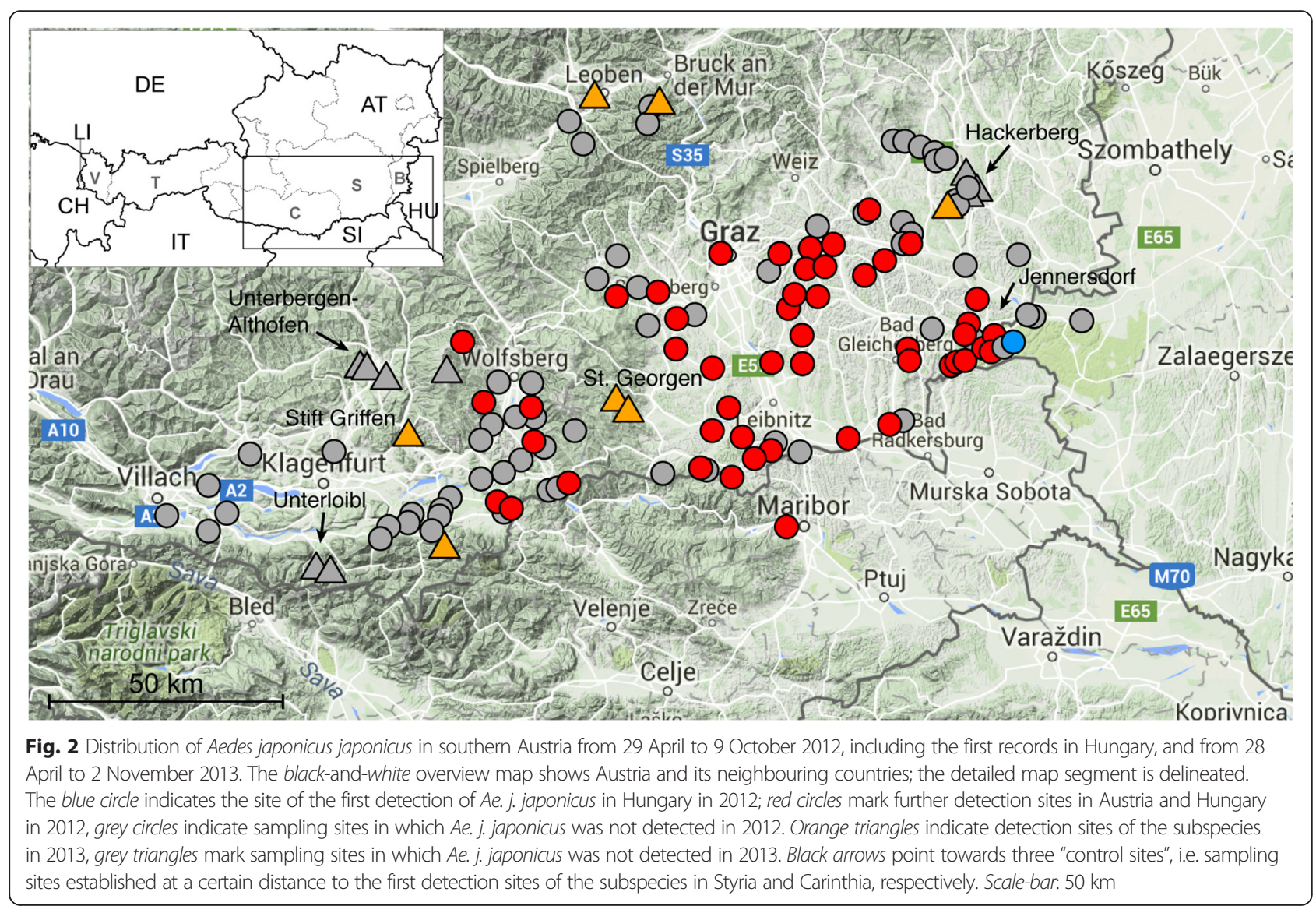


bordering Germany, Switzerland, and the Principality of Liechtenstein. For example, the area in and around the village of Hohenweiler was checked on 28 September 2011, 27 September 2012, 5 September 2013, 3 October 2013 and 10 October 2014, without evidence for presence of Ae. j. japonicus. The same result was obtained in the area of Lustenau, which was for the first time investigated for mosquito larvae in 2014. From 2011 to 2014 only adult Culex pipiens, Cx. hortensis, and Ae. geniculatus were caught in this area. However, on 27 April 2015 twelve 3rd instar larvae specimens of Ae. j. japonicus were collected in the village of Hohenweiler, close to the German border, out of two $200 \mathrm{l}$ water vessels, without any other culicid species (except two Culex egg-rafts), representing the first detection of Ae. j. japonicus in western Austria. From 11 to 13 May 2015 we extended our sampling area to several other districts of Vorarlberg as well as to neighbouring areas of Bavaria (Germany) and Switzerland, and succeeded to detect Ae. j. japonicus at numerous locations (Table 1). To add to the VectorNet data base for Ae. $j$. japonicus, sampling was performed in Liechtenstein, by inspecting man-made containers in cemeteries or gardens. On 29 June 2015 the first and only location checked, a cemetery in the village of Schaan, was found to be positive for the subspecies. On 17 July 2015 the subspecies was found in two additional locations in Liechtenstein, i.e. in

Table 1 Aedes japonicus japonicus findings between 27 April and 17 July 2015 in the westernmost Austrian province of Vorarlberg and adjacent areas of Bavaria (Germany), Switzerland and Liechtenstein

\begin{tabular}{|c|c|c|c|c|}
\hline Country/Locality & Date & Latitude & Longitude & $\begin{array}{l}\text { Altitude } \\
\text { (m.a.s.l.) }\end{array}$ \\
\hline \multicolumn{5}{|l|}{ Austria } \\
\hline Hohenweiler $^{a}$ & 27 April 2015 & $47.587890 \mathrm{~N}$ & $9.781830 \mathrm{E}$ & 482 \\
\hline Lustenau & 12 May 2015 & $47.403045 \mathrm{~N}$ & $9.671896 \mathrm{E}$ & 404 \\
\hline Hörbranz & 12 May 2015 & $47.567728 \mathrm{~N}$ & $9.764382 \mathrm{E}$ & 416 \\
\hline Lustenau & 13 May 2105 & $47.438850 \mathrm{~N}$ & $9.684357 \mathrm{E}$ & 395 \\
\hline \multicolumn{5}{|l|}{ Bavaria (Germany) } \\
\hline Scheidegg ${ }^{a}$ & 11 May 2015 & $47.591945 \mathrm{~N}$ & $9.845972 \mathrm{E}$ & 728 \\
\hline Niederstaufen & 12 May 2015 & $47.596926 \mathrm{~N}$ & $9.808601 \mathrm{E}$ & 576 \\
\hline Niederstaufen & 12 May 2015 & $47.597191 \mathrm{~N}$ & $9.795113 \mathrm{E}$ & 526 \\
\hline \multicolumn{5}{|l|}{ Switzerland } \\
\hline St. Margarethen & 12 May 2015 & $47.442074 \mathrm{~N}$ & $9.640852 E$ & 424 \\
\hline \multicolumn{5}{|l|}{ Liechtenstein } \\
\hline Schaan ${ }^{a}$ & 29 June 2015 & $47.168118 \mathrm{~N}$ & $9.513211 \mathrm{E}$ & 465 \\
\hline Nendeln & 17 July 2015 & $47.200786 \mathrm{~N}$ & $9.545800 \mathrm{E}$ & 462 \\
\hline Mauren & 17 July 2015 & $47.218708 \mathrm{~N}$ & $9.540176 \mathrm{E}$ & 460 \\
\hline
\end{tabular}

${ }^{\mathrm{a}}$ First records for Vorarlberg, Bavaria and the Principality of Liechtenstein, respectively

Abbreviation: m.a.s.l. metres above sea level the villages of Nendeln and Mauren (at a distance of approximately $12 \mathrm{~km}$ to Schaan).

The last findings of Ae. j. japonicus in 2015 were from sampling sites located close to the city of Kufstein (20 September 2015; 47.583840N, 12.154703E; 505 m.a.s.l.) in the lower Inn valley of the Tyrol and up in the alpine Montafon valley of Vorarlberg (10 October 2015; 47.03461N, 009.95174E; 713 m.a.s.l.). Since all known established populations are $>50 \mathrm{~km}$ away from the Kufstein location (the closest is the recently identified one in Upper Bavaria/Salzburg [5]), the introduction to this Tyrolean location might have been passive.

The distribution of Ae. j. japonicus in western Austria, neighbouring Germany and the Principality of Liechtenstein in 2015 is shown in Fig. 3.

\section{Conclusions}

Our findings demonstrate an ongoing spread of $A e . j$. japonicus in Austria towards all directions. The spread into western Austria, observed in 2015, is most likely a result from the active expansion of the population established in Switzerland. The easternmost location of that population was Zurich (Witikon, 47 361944N, $8^{\circ}$ $603056 E$ ) in 2008 [4], and the subspecies was found in other eastern Swiss cantons during the following years (F. Schaffner, unpublished data) up to reaching the Austrian border. Hence it has spread eastwards over around $100 \mathrm{~km}$ in 7 years. Also the Principality of Liechtenstein was shown to be colonised in 2015, but first introduction and establishment could have happened there earlier, which can be excluded for the surveyed sites in Vorarlberg, Austria. Meanwhile, Ae. j. japonicus has reached northern Italy via the Austrian province of Carinthia [13], Croatia via Slovenia (Merdić, in [14]), and north-eastern France spreading from neighbouring Switzerland [15]. It will probably reach the Austrian capital Vienna and the Hungarian tourist region of Lake Balaton within the upcoming few years.

Aedes $j$. japonicus is not considered a mosquito subspecies posing a major risk in terms of pathogen transmission [1, 16]. Thus, little is done to control its populations in most European countries. However, this mosquito has the potential to play a role in transmission of pathogens like flaviviruses of the Japanese encephalitis complex (West Nile, Japanese encephalitis, and Saint Louis encephalitis viruses) $[1,16]$; recent findings support a major role in transmission of La Crosse virus in North America [17]. Moreover, the subspecies can pose a nuisance in forested areas [F. Schaffner, unpublished data], and it was identified as candidate bridge vector for WNV transmission in Switzerland, based on abundance data, spatio-temporal activity, host preferences, and laboratory vector competence for WNV [18]. This, together with the rapid spread observed, 


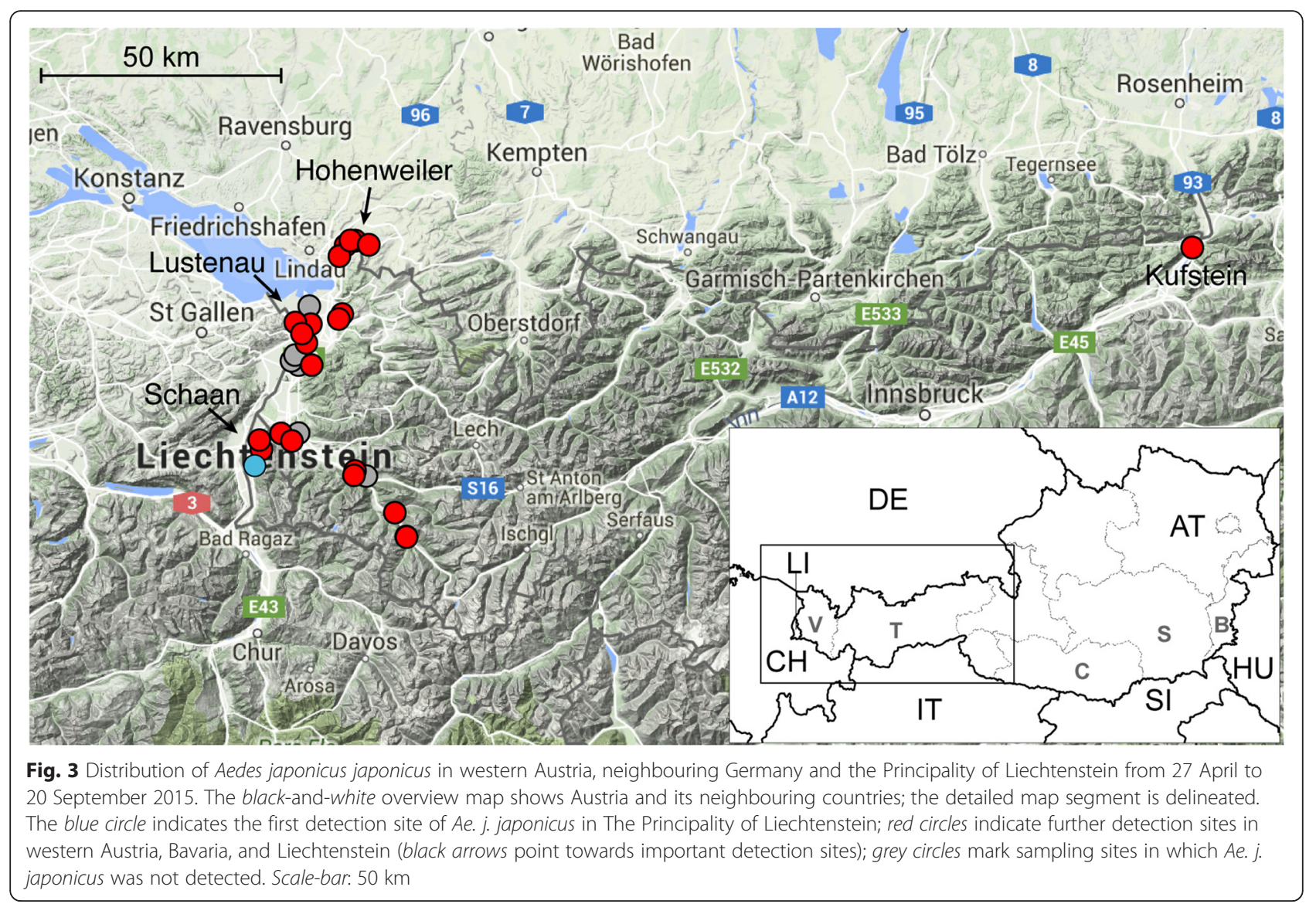

argues for the implementation of long term surveillance and response preparedness as well as application of adapted and sustainable control measures in order to limit further spread and to reduce the abundance of this invasive mosquito subspecies [19].

\section{Acknowledgements}

Darja Duh from Slovenia, László Papp and Zoltán Soltész from Hungary, Rebecca Jussel and Udo Hagen (Reptile Zoo, Scheidegg, Bavaria) from Germany, Alexander Indra (AGES) and Gerhard Müller (University of Vienna) from Austria provided support and advice. Christian Ademeit (Austria) and Julian Olle (Germany) assisted in the field work (Technical Office of Ecology and Landscape Assessment, Austria). We are grateful to Alexander Mathis (University of Zurich), Wim van Bortel (ECDC) and Sofie Dohlander (EFSA) for their valuable suggestions to improve the manuscript and to Katharina Brugger (Vetmeduni Vienna) for preparing the maps.

\section{Funding}

This study was partially funded by the EU grant FP7-261504 EDENext and the Austrian Climate Research Programme (ACRP7; KR14AC7K1 1954). Part of the work was carried out under the frame of the EurNegVec COST Action TD1303. The publication is catalogued by the EDENext Steering Committee as EDENext438 (http://www.edenext.eu). The contents of this publication are the sole responsibility of the authors and do not necessarily reflect the views of the European Commission. The VectorNet field work was carried out under the framework contract OC/EFSA/AHAW/2013/02-FWC1 funded by the European Food Safety Authority (EFSA) and the European Centre for Disease Prevention and Control (ECDC). The funding bodies had no role in the design of the study and collection, analysis, and interpretation of data and in writing the manuscript.

\section{Availability of data and materials}

The datasets supporting the conclusions of this article are included within the article. The mosquito specimens recorded in this study are available from BS.

\section{Authors' contributions}

BS has mainly designed the study; he performed the field work. FS performed the VectorNet field mission in Liechtenstein. NN, FA, FS and TB contributed to design the study. All authors contributed to drafting the manuscript. They all read the final version and approved its submission.

\section{Competing interests}

All authors declare that they have no competing interests.

\section{Consent for publication}

Not applicable.

\section{Ethics approval and consent to participate}

Not applicable.

\footnotetext{
Author details

${ }^{1}$ Technical Office of Ecology and Landscape Assessment, Nibelungenstrasse 51, A-3680 Persenbeug, Austria. ${ }^{2}$ Department of Theoretical Biology, University of Vienna, Althanstrasse 14, A-1090 Vienna, Austria. ${ }^{3}$ Viral Zoonoses, Emerging and Vector-Borne Infections Group, Institute of Virology, University of Veterinary Medicine, Veterinaerplatz 1, A-1210 Vienna, Austria. ${ }^{4}$ Department of Basic Medical Sciences, College of Medicine, Mohammed Bin Rashid University of Medicine and Health Sciences, Dubai Healthcare City, P.O. Box 505055, Dubai, United Arab Emirates. ${ }^{5}$ Department of Microbiology and Infectious Diseases, Faculty of Veterinary Science, Szent István University, Hungária krt. 23-25, H-1143 Budapest, Hungary. Institute for Medical Microbiology and Hygiene, Austrian Agency for Health and Food Safety (AGES), Waehringerstrasse 25a, A-1096 Vienna, Austria. ${ }^{7}$ Avia-GIS,
} 
Agro-Veterinary Information and Analysis, Risschotlei 33, B-2980 Zoersel, Belgium. ${ }^{8}$ National Centre for Vector Entomology, Institute of Parasitology, University of Zurich, Winterthurerstrasse 266a, CH-8057 Zurich, Switzerland.

Received: 20 May 2016 Accepted: 14 June 2016

Published online: 24 June 2016

\section{References}

1. Medlock JM, Hansford KM, Versteirt V, Cull B, Kampen H, Fontenille D, Hendrickx G, Zeller H, Van Bortel W, Schaffner F. An entomological review of invasive mosquitoes in Europe. Bull Entomol Res. 2015;105:637-63.

2. Wilkerson RC, Lintom YM, Fonseca DM, Schultz TR, Price DC, Strickam DA. Making mosquito taxonomy useful: a stable classification of tribe Aedini that balances utility with current knowledge of evolutionary relationships. PLoS One. 2015;10:e0133602.

3. Versteirt V, Schaffner F, Garros C, Dekoninck W, Coosemans M, Van Bortel W. Introduction and establishment of the exotic mosquito species Aedes japonicus japonicus (Diptera: Culicidae) in Belgium. J Med Entomol. 2009;46:1464-7.

4. Schaffner F, Kaufmann C, Hegglin D, Mathis A. The invasive mosquito Aedes japonicus in Central Europe. Med Vet Entomol. 2009;23:448-51.

5. Zielke DE, Walther D, Kampen H. Newly discovered population of Aedes japonicus japonicus (diptera: culicidae) in upper Bavaria, Germany, and Salzburg, Austria, is closely related to the Austrian/Slovenian bush mosquito population. Parasit Vectors. 2016;9:163.

6. Seidel B, Duh D, Nowotny N, Allerberger F. First record of the mosquitoes Aedes (Ochlerotatus) japonicus japonicus (Theobald, 1901) in Austria and Slovenia 2011 and for Aedes (Stegomyia) albopictus (Skuse, 1895) in Austria 2012. Entomol Zeitschrift. 2012;122:223-6 [in German].

7. Kalan K, Buzan VE, Ivović V. Distribution of two invasive mosquito species in Slovenia. Parasit Vectors. 2014;7(1):9 [abstract].

8. Schaffner F, Chouin S, Guilloteau J. First record of Ochlerotatus (Finlaya) japonicus japonicus (Theobald, 1901) in metropolitan France. J Am Mosq Control Assoc. 2003;19:1-5

9. Kampen $\mathrm{H}$, Zielke D, Werner D. A new focus of Aedes japonicus japonicus (Theobald, 1901) (Diptera, Culicidae) distribution in Western Germany: rapid spread or a further introduction event? Parasit Vectors. 2012;5:284.

10. Balestrino F, Schaffner F, Forgia DL, Paslaru Al, Torgerson PR, Mathis A, Veronesi E. Field evaluation of baited traps for surveillance of Aedes japonicus japonicus in Switzerland. Med Vet Entomol. 2016;30:64-72.

11. Schaffner F, Angel G, Geoffroy B, Hervy JP, Rhaiem A, Brunhes J. The mosquitoes of Europe (CD-Rom) Montpellier: IRD Éditions \& EID Méditerrannée; 2001

12. Tóth $\mathrm{S}$, Kenyeres $Z$. Revised checklist and distribution maps of mosquitoes (Diptera, Culicidae) of Hungary. Eur Mosq Bull. 2012;30:30-65.

13. Seidel B, Montarsi F, Huemer HP, Indra A, Capelli G, Allerberger F, Nowotny N. First record of the Asian bush mosquito, Aedes japonicus japonicus, in Italy: invasion from an established Austrian population. Parasit Vectors. 2016;9:284.

14. Kampen H, Werner D. Out of the bush: the Asian bush mosquito Aedes japonicus japonicus (Theobald, 1901) (Diptera, Culicidae) becomes invasive. Parasit Vectors. 2014;7:59.

15. Krebs $T$, Bindler $P$, L'Ambert G, Toty $C$, Perrin $Y$, Jourdain F. First establishment of Aedes japonicus japonicus (Theobald, 1901) (Diptera: Culicidae) in France in 2013 and its impact on public health. J Vector Ecol. 2014;39:437-40

16. Schaffner F, Medlock JM, Van Bortel W. Public health significance of invasive mosquitoes in Europe. Clin Microbiol Infect. 2013;19:685-92.

17. Harris MC, Dotseth EJ, Jackson BT, Zink SD, Marek PE, Kramer LD, Paulson SL, Hawley DM. La Crosse virus in Aedes japonicus japonicus mosquitoes in the Appalachian Region, United States. Emerg Infect Dis. 2015:21:646-9.

18. Schönenberger AC, Wagner S, Tuten HC, Schaffner F, Torgerson P, Furrer S, Mathis A, Silaghi C. Host preferences of host-seeking and blood-fed mosquitoes in Switzerland. Med Vet Entomol. 2016:30:39-52.

19. Schaffner F, Bellini R, Petrić D, Scholte E-J, Zeller H, Marrama RL. Development of quidelines for the surveillance of invasive mosquitoes in Europe. Parasit Vectors. 2013;6:209.

\section{Submit your next manuscript to BioMed Central and we will help you at every step:}

- We accept pre-submission inquiries

- Our selector tool helps you to find the most relevant journal

- We provide round the clock customer support

- Convenient online submission

- Thorough peer review

- Inclusion in PubMed and all major indexing services

- Maximum visibility for your research

Submit your manuscript at www.biomedcentral.com/submit 